\title{
Dynamic comparison between Daan real-time PCR and Cobas TaqMan for quantification of HBV DNA levels in patients with CHB
}

\author{
Shao-hang Cai ${ }^{1}$, Fang-fang LV ${ }^{2}$, Yong-hong Zhang ${ }^{3}$, Ye-gui Jiang ${ }^{4}$ and Jie Peng ${ }^{1 *}$
}

\begin{abstract}
Background: Hepatitis B virus (HBV) DNA levels are crucial for managing chronic hepatitis B (CHB). It was unclear whether Daan real-time polymerase chain reaction test (Daan test) or COBAS TaqMan HBV DNA Test (Cobas TaqMan) was superior in measuring different HBV DNA levels in clinical specimens.

Methods: We enrolled 67 treatment-naïve, HBV surface antigen-positive CHB patients (high baseline viral levels) who received either lamivudine/adefovir or entecavir. Serum samples were tested at baseline and treatment week 24 using the Daan test and Cobas TaqMan.

Results: In the 67-baseline samples, the HBV DNA levels with the Cobas TaqMan $\left(7.90 \pm 0.73 \log _{10} \mathrm{IU} / \mathrm{mL}\right)$ were significantly greater than those of the Daan test $\left(7.11 \pm 0.44 \log _{10} \mathrm{IU} / \mathrm{mL} ; P<0.001\right)$. Of the 67 24-week samples (low viral levels), the Cobas TaqMan detected 59 (88.1\%; 8 undetected); the Daan test detected 33 (49.3\%; 34 undetected; $P<0.001$ ). The Cobas TaqMan detected HBV DNA in 26 of 34 samples undetectable by the Daan test (range, 1.4-3.7 $\log _{10} \mathrm{IU} / \mathrm{mL}$ ) or $38 \%$ of samples (26/67). The reductions in viral load after 24 weeks of oral antiviral treatment in the 33 samples that were positive for both the Daan test and the Cobas TaqMan test were significantly different (3.59 \pm $1.11 \log _{10} \mathrm{IU} / \mathrm{mL}$ versus $4.87 \pm 1.58 \log _{10} \mathrm{IU} / \mathrm{mL}$, respectively; $\left.P=0.001\right)$. Spearman correlation analysis showed positive correlation between results from two tests $\left(r_{p}=0.602, P<0.001\right)$. The HBV genotypes and the anti-viral treatment did not affect the measurements of the HBV DNA by the Daan assay and the Cobas Taqman assay.
\end{abstract}

Conclusion: The Cobas Taqman was more sensitive at low viral loads than the Daan test and the change from complete to partial virological response could affect clinical decisions. The Cobas Taqman may be more appropriate for detection of HBV DNA levels.

Keywords: HBV DNA quantification, Daan Test, Cobas TaqMan, Hepatitis B virus, Viral load, Serum, HBeAg

\section{Background}

Chronic hepatitis B (CHB) and its chronic sequelae (e.g., cirrhosis and hepatocellular carcinoma (HCC)) are major health problems, especially in Asia [1,2]. Detecting hepatitis $B$ virus (HBV) DNA, a marker of viral replication, strongly indicates evidence of an HBV infection, as HBV surface antigen (HBsAg) is detected [3,4]. The detection of $\mathrm{HBeAg}$ is important, as its presence usually indicates active HBV replication and a higher risk for HCC [5].

\footnotetext{
*Correspondence: pjie138@163.com

${ }^{1}$ NanFang Hospital, Southern Medical University, Guangzhou, Guangdong Province, China

Full list of author information is available at the end of the article
}

Also, the presence of HBeAg may imply an earlier phase or an active infection with HBV [2].

A goal of CHB therapy is to persistently suppress HBV replication [6]. Efficacy of treatment for CHB ranges from $17 \%$ to $53 \%$ [7-9], and is hindered by the development of HBV resistance to ongoing therapy [10]. Measurement of HBV DNA levels is the most direct and effective way to assess HBV management and high HBV DNA levels are risk factors for development of fibrosis, cirrhosis, hepatocellular carcinoma, and drug resistance [11]. Since fluctuations in HBV DNA levels often trigger a modification in the patients' treatment regimen, the accuracy and detection limits of the methods that quantitate HBV DNA levels can influence the clinical decision making process,

\section{Ciomed Central}


including the dosage, the schedule, and subsequently monitoring of CHB patients [12-15]. Yuan and colleagues [13] found that only $38 \%$ of serum samples (161 of 425) of Chinese CHB patients had detectable HBV DNA levels by a liquid hybridization method (Digene Hybrid Capture II test (Digene test; Digene, Gathersburg, MD, USA); but HBV DNA levels were detected in $89 \%$ of these samples $(383 / 425)$ by the real-time polymerase chain reaction (PCR) method, Cobas TaqMan assay (Cobas TaqMan, Roche Molecular Systems, Inc., Branchburg, NJ). Currently, real-time PCR quantification assays are used for measuring HBV DNA due to their sensitivity, specificity, and dynamic range $[12,16,17]$. Accuracy is enhanced when the HBV DNA is assayed within a linear range $[3,13,16]$. Comparison of the accuracy and detectable range between the different PCR tests suggest that the Cobas TaqMan assay (Cobas TaqMan) shows similar sensitivity and specificity rates to the RealArt assay (Abbott, North Chicago, IL USA) [3].

However, to our knowledge, comparisons between the Cobas TaqMan assay and the Daan test of HBV DNA levels have not been performed with clinical samples from patients with both high and low viral loads, particularly those from posttreatment patients who may have very low viral loads. In this multicenter, prospective, cohort study, we aimed to investigate any potential differences in detecting HBV DNA levels between the 2 methods in a clinical setting by testing samples with high or low viral loads taken from Chinese carriers at baseline and after 24 weeks of oral antiviral treatment.

\section{Methods}

\section{Subjects}

This study was a multicenter prospective cohort study. From July, 2011 to March, 2012, we enrolled a cohort of 67 treatment-naive patients (48 males, 19 females), who were diagnosed with hepatitis B virus e antigen ( $\mathrm{HBeAg}$ )-positive $\mathrm{CHB}$ with high viral loads at baseline. Of the 67 patients, eight patients were from Southwest Hospital, six patients were from Sir Run Run Shaw Hospital, eighteen patients were from Second Xiangya Hospital, and the remaining thirty-five patients were from NanFang Hospital. The inclusion criteria were $\mathrm{HBeAg}$-positive $\mathrm{CHB}$ with high viral loads at baseline (HBsAg positive $>6$ months; serum HBV DNA levels $>2 \times 10^{6} \log _{10} \mathrm{IU} / \mathrm{mL}$ by the Daan test). $\mathrm{HBeAg}$ was positive by radioimmunoassay (Abbott Laboratories). We also included patients who had alanine aminotransferase (ALT) levels greater than the upper limit of normal (ULN), documented on 2 separate occasions 2 weeks apart, with the latest ALT $\geq 2 \times$ ULN. Exclusion criteria were evidence of cirrhosis or coinfections with any other viruses, such as hepatitis $C$ virus or human immunodeficiency virus (HIV), or presence of autoimmune hepatitis, alcohol liver disease, or hepatocellular carcinoma.
The Institutional Review Board of Nanfang Hospital, Southern Medical University of the participating sites had approved the study to compare the sensitivity and range of the two assays, Daan test and Cobas PCR test. Each enrolled patient provided informed consent. $\mathrm{Pa}-$ tients were treated with entecavir (ETV) or the combination lamivudine (LAM) plus adefovir (ADV), according to the Chinese guidelines; tenofovir disopril fumarate was not available in China. Because patients may have used economic considerations to choose drug treatment, the drug treatment was not randomized. Forty-one (61.2\%) of the sixty-seven patients received oral antiviral treatment with LAM plus ADV combination therapy, and the remaining twenty-six patients received entecavir (ETV) monotherapy. Blood samples were obtained at baseline and at week 24 and serum samples were collected. All samples were aliquoted and stored immediately at $-80^{\circ} \mathrm{C}$.

\section{Quantification of serum HBV DNA and determination of HBV genotype}

The Daan test was performed at the Nanfang Hospital per the manufacturer's instructions (Daan Gene Co, Ltd of Sun Yat-sen University, Guangdong, China). Briefly, HBV DNA was extracted with control DNA from $100 \mu \mathrm{L}$ of serum and detected by PCR fluorescence probing. The real-time PCR assay was performed in the Roche LightCycler 480 (Roche Diagnostics Ltd, Switzerland) according to the manufacturer's instructions; the PCR amplification reaction used thermus aquaticus DNA polymerase, deoxyribonucleoside triphosphates (dNTPs), and a HBV DNA specific probe to detect and measure serum HBV DNA levels. The manufacturer reports a linear range of $1 \times 10^{2} \mathrm{IU} / \mathrm{mL}$ to $1 \times$ $10^{8} \mathrm{IU} / \mathrm{mL}$.

The Cobas TaqMan assay was performed at the Nanfang Hospital according to the manufacturer's instructions (Roche Molecular Systems, Inc, Pleasanton, CA, USA). The Cobas TaqMan assay is based on the coamplification of target HBV DNA and the detection of a cleaved dual-labeled oligonucleotide detection probe specific to the target. Serum samples of $750 \mu \mathrm{L}$ were transferred for automatic processing. The manufacturer reports a HBV DNA linear range of $20 \mathrm{IU} / \mathrm{mL}$ to $1.7 \times$ $10^{8} \mathrm{IU} / \mathrm{mL}$.

The HBV genotype was determined by nested PCR with the Qiagen Mini Kit (Qiagen), following the manufacturer's instructions.

\section{Follow-up}

The enrolled patients were seen from July 2011 to September 2012 in 1 of 4 teaching hospitals-Nanfang Hospital of Southern Medical University in Guangzhou (43 patients), the Second Xiangya Hospital of Central 
South University in Changsha (13 patients), the Affiliated Sir Run Run Shaw Hospital of Zhejiang University in Hangzhou (3 patients), or Southwest Hospital of the Third Military Medical University in Chongqing (8 patients). Serum ALT (Olympus AU5400) and HBeAg levels (radioimmunoassay) were assessed at week 12. At week 24, serum ALT, HBeAg, and HBV DNA levels were evaluated.

Virological responses were scored according to the guidelines recommended by the European Association for the Study of the Liver (EASL) for nucleos(t)ide analogues (NAs) therapy [6].

\section{Statistical analysis}

Mean and standard deviation (SD) were calculated for continuous variables, and percentages were used for categorical variables. Levels of quantified HBV DNA levels were expressed in logarithmic units $\left(\log _{10} \mathrm{IU} / \mathrm{mL}\right)$. HBV DNA levels with the Cobas TaqMan were assigned as negative, if results were below $20 \mathrm{IU} / \mathrm{mL}$ and thus were considered to be undetectable values. To determine whether the results were statistically different, the $x^{2}$ test, the $t$ test, and the Spearman correlation coefficient were applied, as appropriate. For each pair of measurements, the agreement between the Cobas TaqMan and the Daan test were plotted against their means in a Bland-Altman analysis. The statistical significance of all tests was defined as $P<0.05$ by 2 -tailed tests. Quality control procedures, as well as data analyses, were performed by using MedCalc for Windows, version 9.38 (MedCalc Software, Mariakerke, Belgium).

\section{Results}

\section{Demographics}

Sixty-seven treatment-naïve patients (48 male, 19 female) who were diagnosed with hepatitis $B$ virus e antigen (HBeAg) positive $\mathrm{CHB}$ with high viral load at baseline from July 2011 to March 2012 were enrolled in a multicenter prospective trial. The mean age was $30.6 \pm$ 8.4 years (range: 16 to 61 years) (Table 1 ). HBV genotype B was found in 43 patients (64.2\%, all B2 subgenotype) and HBV genotype $\mathrm{C}$ was found in 24 patients $(35.8 \%$; 17 with subgenotype $\mathrm{C} 1$ and 7 with $\mathrm{C} 2$ subgenotype). Forty-one out of the 67 patients (61.2\%) received oral antiviral treatment with de novo lamivudine (LAM) and adefovir (ADV) combination therapy and 26 patients received entecavir (ETV).

\section{Virological responses}

The results from the Daan test indicated that 34 patients (50.7\%) achieved virological responses and 33 patients (49.3\%) attained partial virological responses. The HBV DNA levels obtained by the Cobas TaqMan assay indicated that 8 patients $(11.9 \%)$ patients had virological responses and 58 patients $(86.6 \%)$ had partial virological
Table 1 Demographic and virologic characteristics of the study patients

\begin{tabular}{|c|c|}
\hline & $n=67$ \\
\hline$\overline{\text { Age }(\text { years) }})^{a}$ & $30.6 \pm 8.4$ \\
\hline \multicolumn{2}{|l|}{ Gender, n (\%) } \\
\hline Male & $48(71.6)$ \\
\hline Female & $19(28.4)$ \\
\hline \multicolumn{2}{|l|}{ Treatment, n (\%) } \\
\hline Lamivudine plus adefovir & $41(61.2)$ \\
\hline Entecavir & $26(38.8)$ \\
\hline $\operatorname{ALT}(I U / m L)^{a}$ & $202.9 \pm 137.9$ \\
\hline \multicolumn{2}{|l|}{ HBV DNA $\left(\log _{10} \mathrm{IU} / \mathrm{mL}\right)$} \\
\hline Daan Test ${ }^{\mathrm{a}, \mathrm{b}}$ & $7.11 \pm 0.44$ \\
\hline Cobas TaqMan ${ }^{\mathrm{a}, \mathrm{b}}$ & $7.90 \pm 0.73$ \\
\hline
\end{tabular}

responses. Thus, the clinical assessments of the 34 samples by the two assays were significantly different $(\mathrm{P}<$ 0.001). In particular, 1 study patient who was classified as a partial virological responder by the Daan Test was classified as a primary non-responder by the Cobas TaqMan assay. Therefore, this comparison indicates that the more sensitive assay can alter clinical decisions and is crucial for managing $\mathrm{CHB}$ patients.

\section{Comparison of assays for measuring high HBV viral load in clinical samples}

The HBV DNA levels of the 67 serum samples at baseline showed a high viral load and were detected by both the Cobas TaqMan and the Daan tests. All 67 baseline serum samples were quantitated by the Daans test whereas 27 of 67 of these baseline samples needed to be diluted for quantification by the Cobas TaqMan test (17 samples had HBV B genotype and 10 samples $\mathrm{C}$ genotype). The differences in the viral load of the 27 samples ranged from $<0.5 \log _{10} \mathrm{IU} / \mathrm{mL}$ in 3 samples (11.1\%) to between $0.5 \log _{10} \mathrm{IU} / \mathrm{mL}$ and $1 \log _{10} \mathrm{IU} / \mathrm{mL}$ in 10 samples (37.0\%) to $\geq 1 \log _{10} \mathrm{IU} / \mathrm{mL}$ in 14 samples (51.9\%). Forty samples were measured without dilution by the Cobas TaqMan test (26 had B genotype and 14 had $C$ genotype). Genotypes were not significantly different at baseline viral load $(\mathrm{p}=0.87)$.

The mean baseline viral load of patients treated with LAM/ADV and assessed by Cobas TaqMan (8.02 \pm $0.57 \log _{10} \mathrm{IU} / \mathrm{mL}$ ) was significantly higher than those assessed by Daan test $\left(7.01 \pm 0.43 \log _{10} \mathrm{IU} / \mathrm{mL} ; \mathrm{P}<\right.$ 0.001). Likewise, the mean baseline viral load of patients treated with ETV assessed with the Cobas TaqMan (7.71 \pm $0.90 \log _{10} \mathrm{IU} / \mathrm{mL}$ ) was significantly greater than those assessed by the Daan test $\left(7.13 \pm 0.46 \log _{10} \mathrm{IU} / \mathrm{mL} ; \mathrm{P}=\right.$ 0.002). Thus, HBV DNA levels with the Cobas TaqMan 
were significantly greater than that of the Daan Test $\left(7.90 \pm 0.72 \log _{10} \mathrm{IU} / \mathrm{mL}\right.$ versus $7.11 \pm 0.44 \log _{10} \mathrm{IU} / \mathrm{mL}$, respectively; $P<0.001)$. Of note, the level of high viral load $\left(\geq 7 \log _{10} \mathrm{IU} / \mathrm{mL}\right)$ detected by the Cobas TaqMan test $(8.09 \pm 0.43)$ significantly differed from that of the Daan test $(7.14 \pm 0.43)(P<0.001)$.

\section{Comparison of assays for measuring low HBV viral load (week 24 posttreatment clinical samples)}

Another 67 serum samples were obtained from the patients at week 24 post treatment: the HBV DNA levels of only 33 clinical samples were detected by both assays. No significant differences were observed between the average HBV DNA levels with the Cobas TaqMan assay $\left(3.25 \pm 1.37 \log _{10} \mathrm{IU} / \mathrm{mL}\right.$; range, from $1.34 \log _{10} \mathrm{IU} / \mathrm{mL}$ to $6.41 \log _{10} \mathrm{IU} / \mathrm{mL}$ ) of these 33 posttreatment samples and those determined with the Daan test $(3.52 \pm 0.97$ $\log _{10} \mathrm{IU} / \mathrm{mL}$; range, from $2.20 \log _{10} \mathrm{IU} / \mathrm{mL}$ to $6.86 \log _{10}$ $\mathrm{IU} / \mathrm{mL})(P=0.19)$. The correlation coefficient for the HBV DNA levels in these 33 samples detected by these two assays was 0.56 (Spearman correlation, $P=0.001$ ). The divergence in the HBV DNA levels between both assays was within $0.5 \log _{10} \mathrm{IU} / \mathrm{mL}$ and was found in only 10 samples.

The Cobas TaqMan test detected HBV DNA levels in 59 of the 67 week 24 serum samples (88.1\%) whereas the Daan test detected HBV DNA levels in 33 of the 67 week 24 serum samples $(49.7 \%)(P<0.001)$. Thus, the Cobas TaqMan test quantitated HBV DNA levels in 26 of the 34 serum samples that had HBV DNA levels below the linear range of Daans test. The minimal value of these 26 samples was $1.44 \log _{10} \mathrm{IU} / \mathrm{mL}$, the maximal value was $3.66 \log _{10} \mathrm{IU} / \mathrm{mL}$, and the mean was $2.15 \pm$ $0.58 \log \mathrm{IU} / \mathrm{mL}$.

The 24 week patient samples that tested positive by Cobas TaqMan showed no marked difference in HBV genotypes: HBV genotype B was present in $83.72 \%$ of samples and $C$ in $95.83 \%$ samples, $(P=0.14)$. The patient samples that tested positive by Daans also showed no significant difference among genotypes: $44.2 \%$ of samples contained HBV genotypes B and 58.33\% contained HBV genotype $C(P=0.26)$. Multivariate Analysis of Variance (MANOVA) was employed to analyze the HBV DNA determined by Cobas TaqMan assay and Daan test. Results showed HBV genotypes had no influence on the HBV DNA level $(P=0.471)$.

The mean reduction of viral load from baseline to samples after 24 week treatment with LAM/ADV or ETV was not significantly different between the two assays. The mean reduction of viral load in LAM/ADV group by the Cobas TaqMan $(5.47 \pm 1.53 \log \mathrm{IU} / \mathrm{mL})$ was similar to that by the Daan test $\left(5.32 \pm 1.96 \log _{10} \mathrm{IU} / \mathrm{mL}\right.$; $\mathrm{P}=0.57$ ). The mean reductions of viral load in the ETV group after 24 weeks assessed by the Cobas TaqMan $\left(5.20 \pm 1.17 \log _{10} \mathrm{IU} / \mathrm{mL}\right)$ was similar to that assessed by the Daan test $\left(29 \pm 1.83 \log _{10} \mathrm{IU} / \mathrm{mL} ; \mathrm{P}=0.8\right)$.

\section{Association analyses between the Cobas TaqMan assay and the Daan test}

The HBV DNA levels of the 100 positive samples of the 134. (67 at baseline; 67 at week 24) samples detected by the Daan test were well correlated to those detected by the Cobas TaqMan $\left(r_{p}=0.79 ; P<0.001\right.$; Figure 1$)$. The reductions in viral load after 24 weeks of oral antiviral treatment in the 33 samples that were positive for both the Daan and the Cobas TaqMan tests were significantly different $\left(3.59 \pm 1.11 \log _{10} \mathrm{IU} / \mathrm{mL}\right.$ versus $4.87 \pm 1.58$ $\log _{10} \mathrm{IU} / \mathrm{mL}$, respectively; $P=0.001$ ). Spearman correlation analysis showed positive correlation between results from two tests $\left(r_{p}=0.602, P<0.001\right)$. However, according to the results from the Daan test, 34 patients (34/67; 50.7\%) had undetectable HBV DNA levels, and 33 patients $(33 / 67,49.3 \%)$ had decreases in HBV DNA levels of more than $1 \log _{10} \mathrm{IU} / \mathrm{mL}$ from baseline (but were still detectable) after 24 weeks on treatment. In comparison, the results of the Cobas TaqMan test indicated that 8 patients $(8 / 67 ; 11.9 \%)$ had undetectable HBV DNA levels, and 58 patients $(58 / 67 ; 86.6 \%)$ showed decreases in HBV DNA levels of more than $1 \log _{10}$ $\mathrm{IU} / \mathrm{mL}$ (but were still detectable) after 24 weeks on therapy $(P<0.001)$. A reduction of HBV viral load in one patient $(1 / 67 ; 1.5 \%)$ varied from $1.38 \log _{10} \mathrm{IU} / \mathrm{mL}$ with the Daan Test to $-0.42 \log _{10} \mathrm{IU} / \mathrm{mL}$ with the Cobas TaqMan.

\section{Agreement analyses between the Cobas TaqMan assay and the Daan test}

A Bland-Altman plot was used to visualize the differences between HBV DNA quantitation of both baseline and posttreatment serum samples $(n=134)$ by the two methods (Figure 2). At baseline, the mean difference between the Cobas TaqMan assay and the Daan test was $-0.79 \log _{10}$ $\mathrm{IU} / \mathrm{mL}$, with limits of agreement from $-2.20 \log _{10} \mathrm{IU} / \mathrm{mL}$ to $0.63 \log _{10} \mathrm{IU} / \mathrm{mL}$. The HBV DNA levels in the baseline high viral loads $\left(>10^{6} \mathrm{IU} / \mathrm{mL}\right)$ determined with the Daan test were lower than those determined by the Cobas Taqman test. In contrast, at 24-week postteatment, the Cobas TaqMan and the Daan test showed good agreement on low viral load HBV DNA levels, with the mean difference of $-0.3 \log _{10} \mathrm{IU} / \mathrm{mL}$ and with limits of agreement from $-2.6 \log _{10} \mathrm{IU} / \mathrm{mL}$ to $2.1 \log _{10} \mathrm{IU} / \mathrm{mL}$.

\section{Discussion}

The HBV DNA levels from the 134 samples detected by both the Daan test and Cobas TaqMan were, in general, concordant. The HBV genotypes and the anti-viral therapy did not significantly affect the measurement of the viral loads by either the Daan or the Cobas Taqman 


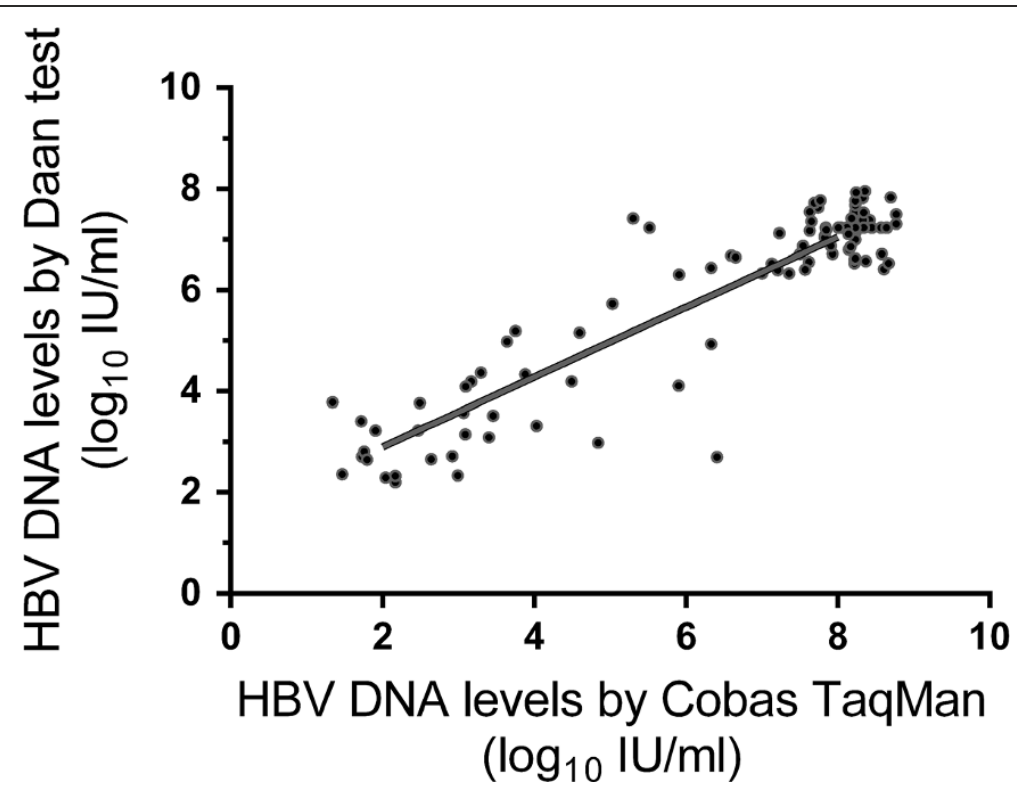

Figure 1 The correlation of 2 methods in a total of the hundred positive of the 134 samples. The Spearman's correlation coefficient in HBV DNA level between the 2 methods was $r_{p}=0.79(P<0.001)$.

assays. However, through further stratified analyses that accounted for the significant differences in the high viral load samples $\left(>7 \log _{10} \mathrm{IU} / \mathrm{mL}\right)$, we conclude that the Cobas TaqMan assay was superior to that of the Daan test. Therefore, it might be necessary to reconsider the usage of the Daan test because the Daan test was not as sensitive in detecting and quantifying HBV DNA levels as the Cobas TaqMan test in our study.

Serum HBV DNA levels are key indicators for $\mathrm{CHB}$ management, including assessing treatment initiation, treatment response, and drug withdrawal $[6,18]$. A more effective and sensitive method to detect HBV DNA levels could assist in improving key medical decisions and clinical patient management [19]. Current studies have demonstrated that monotherapy with a high resistance barrier agent or de novo combination therapy is a more appropriate choice for $\mathrm{CHB}$ patients with high baseline HBV DNA levels, as the risk of resistance and treatment failure are associated with high viral loads [20]. In order to avoid the emergence of drug resistant HBV [21,22], HBV DNA levels should be confirmed as early as possible. According to the results of the current study, viral load monitoring and HBV DNA detection were superior using the Cobas TaqMan assay to identify
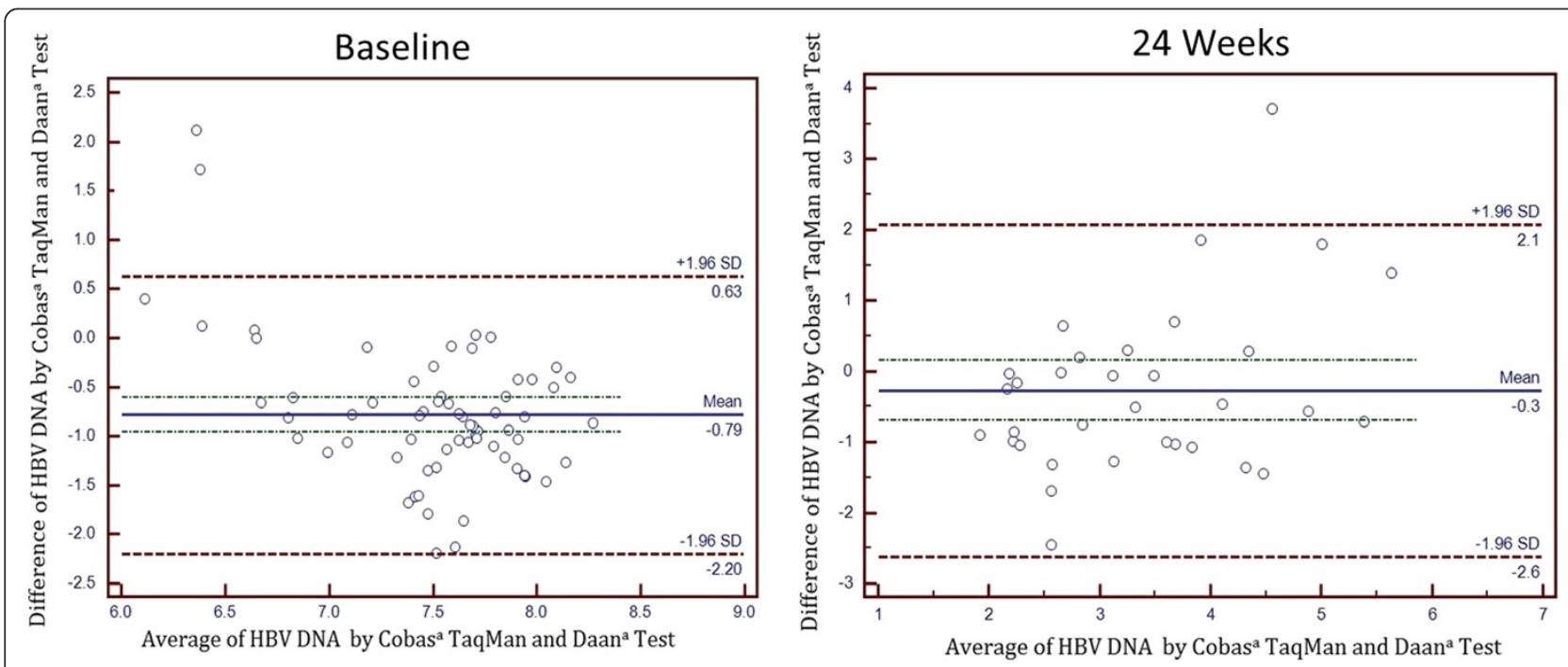

Figure 2 A Bland-Altman plot of the Cobas TaqMan assay and Daan test at baseline and 24 weeks post treatment. 
a virological response, a partial virological response, or a primary non-response.

Drug withdrawal is another key problem in CHB management. According to the most recently proposed guidelines, treatment withdrawal could be considered if the HBV DNA levels remained undetectable for at least 12 months, as documented on 2 separate occasions, which were 6 months apart, in HBeAg-positive patients. The treatment for HBeAg-negative patients would be continued for at least 18 months, if undetectable HBV DNA levels could be documented on 3 separate occasions, which were 6 months apart $[6,18,23]$. Due to the significant differences in the undetectable rates in the low viral load samples between the Daan test and the Cobas TaqMan assay $(50.7 \%$ versus $11.9 \%$ respectively, $P<0.001$ ), we believe it is necessary to measure the HBV DNA levels with the Cobas TaqMan assay to further confirm if the HBV DNA levels are negative, even if the HBV DNA levels were undetectable by the Daan test.

This study had a few limitations. This study had a small sample size, which may limit the generalizability of the current findings. Further research which utilizes statistical analyses to determine an appropriate sample size for sufficient statistical power is warranted to validate the current findings. Additionally, we only examined the HBV DNA levels at baseline and at 24 weeks. As such, we suggest additional examinations using these 2 tests at different times with larger sample sizes. Furthermore, more comprehensive studies with multiple detections by these same 2 kits are needed to confirm reproducibility and to determine if the Cobas TaqMan assay may deserve a greater priority than that of the Daan Test. Because the cost of the Cobas Taqman (500 yen) is greater than the Daan test (160 yen), a cost-benefit analysis also would be useful.

\section{Conclusions}

Our results show that the Cobas TaqMan assay was more sensitive in detecting viral loads than the Daan test. Therefore, we do not think physicians should replace the Cobas TaqMan assay with the Daan real-time PCR test in terms of accurate quantitation. In particular, at moments of critical decisions, such as treatment initiation, switch of regimens, judgment of treatment efficacy and treatment cessation, the Cobas TaqMan test should be the first choice. This is because in some cases, the HBV DNA level may be lower than the detection limit of the Daan test, and the change from complete to partial virological response can affect clinical decisions.

However, given the low cost of the Daan test, physicians may consider using this method to monitor disease progression of patients during the immune-tolerant phase and of $\mathrm{HBeAg}$ positive patients for their mid to high HBV DNA levels.

\section{Abbreviations}

HBV: Hepatitis B virus; CHB: Chronic hepatitis B; Daan test: Daan real-time polymerase chain reaction test; Cobas TaqMan: COBAS TaqMan HBV DNA Test; HCC: Hepatocellular carcinoma; HBsAg: HBV surface antigen;

HBeAg: Hepatitis B virus e antigen; PCR: Polymerase chain reaction; ALT: Alanine aminotransferase; ULN: Upper limit of normal; HIV: Human immunodeficiency virus; LAM: Lamivudine; ADV: Adefovir; ETV: Entecavir; dNTPS: Deoxyribonucleoside triphosphates; SD: Standard deviation; NAs: Nucleos(t)ide analogues; EASL: European association for the study of the liver.

\section{Competing interests}

The authors declare that they have no competing interests.

\section{Authors' contributions}

We declare that all the listed authors have participated actively in the study and all meet the requirements of the authorship. JP conceived and designed the study, and wrote the protocol, SHC managed the literature searches and analyses, undertook the statistical analysis, and wrote the first draft of the manuscript. FFL, YHZ and YGJ conducted patient follow-up, and provided important research specimens. All authors read and approve the manuscript.

\section{Acknowledgements}

This work was supported by Chinese Foundation for Hepatitis Prevention and Control (GHF 2011206) and Foundation of GuangDong Pharmaceutical Association (2011G28).

\section{Author details}

${ }^{1}$ NanFang Hospital, Southern Medical University, Guangzhou, Guangdong Province, China. ${ }^{2}$ Sir Run Run Shaw Hospital, Zhejiang University, Hangzhou, Zhejiang Province, China. ${ }^{3}$ Second Xiangya Hospital, Central South University, Changsha, Hunan Province, China. ${ }^{4}$ Southwest Hospital, the Third Military Medical University, Chongqing, China.

Received: 18 June 2013 Accepted: 10 February 2014

Published: 14 February 2014

\section{References}

1. Liaw YF: Antiviral therapy of chronic hepatitis B: opportunities and challenges in Asia. J Hepatol 2009, 51:403-410.

2. Chen P, Yu C, Wu W, Wang J, Ruan B, Ren J, Yang S, Xu K, Yu L, Li L: Serological profile among $\mathrm{HBsAg-positive} \mathrm{infections} \mathrm{in} \mathrm{Southeast} \mathrm{China:}$ a community-based study. Hepat Mon 2013, 13:e7604.

3. Lin YY, Huang JF, Liu SF, Yu ML, Tsai CH, Yang JF, Lin IL, Dai CY, Lin ZY, Chen SC, Chang WY, Chuang WL: Performance characteristics of two real-time PCR assays for quantification of hepatitis $B$ virus DNA. Scand J Infect Dis 2009, 41:614-618.

4. Lok AS, McMahon BJ: Chronic hepatitis B. Hepatology 2007, 45:507-539.

5. Yang HI, Lu SN, Liaw YF, You SL, Sun CA, Wang LY, Hsiao CK, Chen PJ, Chen DS, Chen CJ: Hepatitis B e antigen and the risk of hepatocellular carcinoma. N Engl J Med 2002, 347:168-174.

6. European Association for the Study of the Liver: EASL clinical practice guidelines: management of chronic hepatitis B virus infection. J Hepatol 2012, 57:167-185.

7. Karabay O, Tuna N, Esen S: Comparative efficacy of pegylated interferons alpha-2a and $2 \mathrm{~b}$ in the treatment of $\mathrm{HBeAg}$-negative chronic hepatitis $\mathrm{B}$ infection. Eur J Gastroenterol Hepatol 2012, 24:1296-1301.

8. Wang Y, Thongsawat S, Gane EJ, Liaw YF, Jia J, Hou J, Chan HL, Papatheodoridis G, Wan M, Niu J, Bao W, Trylesinski A, Naoumov NV: Efficacy and safety of continuous 4-year telbivudine treatment in patients with chronic hepatitis B. J Viral Hepat 2013, 20:e37-e46.

9. Dogan UB, Golge N, Akin MS: The comparison of the efficacy of pegylated interferon alpha-2a and alpha-2b in chronic hepatitis B patients. Eur J Gastroenterol Hepatol 2013.

10. Yang JX, Liu BM, Li XG, Yan CH, Xu J, Sun XW, Wang YH, Jiao XJ, Yan L, Dong JP, Hou CS, Abuduheilili X, Li T, Zhuang H: Profile of HBV antiviral resistance mutations with distinct evolutionary pathways against nucleoside/nucleotide analogue treatment among Chinese chronic hepatitis B patients. Antivir Ther 2010, 15:1171-1178.

11. Cai T, Lou G, Yang J, Xu D, Meng Z: Development and evaluation of real-time loop-mediated isothermal amplification for hepatitis $B$ virus 
DNA quantification: a new tool for HBV management. J Clin Virol 2008, 41:270-276.

12. Dai CY, Yu ML, Chen SC, Lin ZY, Hsieh MY, Wang LY, Tsai JF, Chuang WL, Chang WY: Clinical evaluation of the COBAS Amplicor HBV monitor test for measuring serum HBV DNA and comparison with the Quantiplex branched DNA signal amplification assay in Taiwan. J Clin Pathol 2004, 57:141-145

13. Yuan HJ, Yuen MF, Wong DK, Sum SS, Lai CL: Clinical evaluation of the digene hybrid capture II test and the COBAS AMPLICOR monitor test for determination of hepatitis B virus DNA levels. J Clin Microbiol 2004, 42:3513-3517.

14. Yim HJ, Byun KS, Chang YJ, Suh YS, Yeon JE, Lee CH, Kwon JA, Yoo W, Kim SO, Hong SP: Levels of hepatitis B virus (HBV) replication during the nonreplicative phase: HBV quantification by real-time PCR in Korea. Dig Dis Sci 2007, 52:2403-2409.

15. Abe A, Inoue K, Tanaka T, Kato J, Kajiyama N, Kawaguchi R, Tanaka S, Yoshiba M, Kohara M: Quantitation of hepatitis B virus genomic DNA by real-time detection PCR. J Clin Microbiol 1999, 37:2899-2903.

16. Shi M, Zhang Y, Zhu YH, Zhang J, Xu WJ: Comparison of real-time polymerase chain reaction with the COBAS Amplicor test for quantitation of hepatitis B virus DNA in serum samples. World J Gastroenterol 2008, 14:479-483.

17. Welzel TM, Miley WJ, Parks TL, Goedert JJ, Whitby D, Ortiz-Conde BA: Real-time PCR assay for detection and quantification of hepatitis $B$ virus genotypes A to G. J Clin Microbiol 2006, 44:3325-3333.

18. Liaw YF, Leung N, Kao JH, Piratvisuth T, Gane E, Han KH, Guan R, Lau GK, Locarnini S: Asian-Pacific consensus statement on the management of chronic hepatitis B: a 2008 update. Hepatol Int 2008, 2:263-283.

19. Mangia A, Antonucci F, Brunetto M, Capobianchi M, Fagiuoli S, Guido M, Farci P, Lampertico P, Marzano A, Niro G, Pisani G, Prati D, Puoti M, Raimondo G, Santantonio T, Smedile A, Lauria F, Italian Association for the Study of the Liver (AISF): The use of molecular assays in the management of viral hepatitis. Dig Liver Dis 2008, 40:395-404.

20. Lampertico $P$, Vigano M, Manenti E, lavarone $M$, Lunghi G, Colombo M: Adefovir rapidly suppresses hepatitis B in $\mathrm{HBeAg}$-negative patients developing genotypic resistance to lamivudine. Hepatology 2005, 42:1414-1419

21. Papatheodoridis GV, Dimou E, Dimakopoulos K, Manolakopoulos S, Rapti I, Kitis G, Tzourmakliotis D, Manesis E, Hadziyannis SJ: Outcome of hepatitis B e antigen-negative chronic hepatitis $B$ on long-term nucleos(t)ide analog therapy starting with lamivudine. Hepatology 2005, 42:121-129.

22. Sung JJ, Lai JY, Zeuzem S, Chow WC, Heathcote EJ, Perrillo RP, Brosgart CL, Woessner MA, Scott SA, Gray DF, Gardner SD: Lamivudine compared with lamivudine and adefovir dipivoxil for the treatment of HBeAg-positive chronic hepatitis B. J Hepatol 2008, 48:728-735.

23. Lok AS, McMahon BJ: Chronic hepatitis B: update 2009. Hepatology 2009, 50:661-662.

doi:10.1186/1471-2334-14-85

Cite this article as: Cai et al:: Dynamic comparison between Daan real-time PCR and Cobas TaqMan for quantification of HBV DNA levels in patients with CHB. BMC Infectious Diseases 2014 14:85.

\section{Submit your next manuscript to BioMed Central and take full advantage of:}

- Convenient online submission

- Thorough peer review

- No space constraints or color figure charges

- Immediate publication on acceptance

- Inclusion in PubMed, CAS, Scopus and Google Scholar

- Research which is freely available for redistribution

Submit your manuscript at www.biomedcentral.com/submit
C BioMed Central 